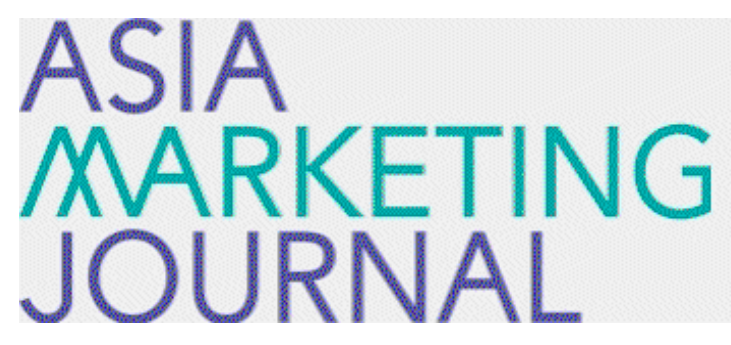

ASIA MARKETING JOURNAL

Volume 15 | Issue 4

Article 6

$1-30-2014$

\title{
Is corporate rebranding a double-edged sword? Consumers ambivalence towards corporate rebranding of familiar brands
}

Grace Ing Phang

Follow this and additional works at: https://amj.kma.re.kr/journal

Part of the Marketing Commons

\section{Recommended Citation}

Phang, Grace Ing (2014) "Is corporate rebranding a double-edged sword? Consumers`ambivalence towards corporate rebranding of familiar brands," Asia Marketing Journal: Vol. 15 : Iss. 4 , Article 6. Available at: https://doi.org/10.53728/2765-6500.1569

This Article is brought to you for free and open access by Asia Marketing Journal. It has been accepted for inclusion in Asia Marketing Journal by an authorized editor of Asia Marketing Journal. 


\section{Is corporate rebranding a double-edged sword? Consumers' ambivalence towards corporate rebranding of familiar brands}

Grace Ing, Phang*

Corporate rebranding has been evident in the qualitative corporate rebranding studies as an imposed organizational change that induces mixed reactions and ambivalent attitudes among consumers. Corporate rebranding for the established and familiar corporate brands leads to more ambivalent attitudes as these companies represent larger targets for disparaging information. Consumers are found to hold both positive and negative reactions toward companies and brands that they are familiar with. Nevertheless, the imposed change assumption and ambivalent attitude, in particular corporate rebranding, have never been widely explored in the quantitative corporate rebranding studies.

This paper aims to provide a comprehensive empirical examination of the ambivalence towards rebrandingrebranded brand attitude-purchase intention relationships. The author proposes that corporate rebranding for familiar corporate brands is a double-edged sword that not only raises the expectation for better performance, but also induces conflicted and ambivalent attitudes among consumers. These consumers' ambivalent attitudes are influenced by both the parent brands-related and general attitude factors which further affect their rebranded brand attitude and purchase intention. A total of 156 useable questionnaires were collected from Malaysian working adults; and two established Malaysian airfreight operators were utilized as the focal parent brands. The study found a significant impact of prior parent brand attitudes on ambivalence towards rebranding (ATR). The parent brand attitudes served as anchors in influencing how new information was processed (Mazaheri et al., 2011; Sherif \& Hovland, 1961) and closely related to behavioral intention (Prislin \& Quellete, 1996). The ambivalent attitudes experienced were higher when individuals held both positive and negative reactions toward the parent brands. Consumers also held higher ambivalent attitudes when they preferred one of the parent brands; while disliked the other brand.

The study also found significant relationships between the lead brand and the rebranded brand attitude; and between the partner brands and ATR. The familiar but controversial partner brand contributed significantly to the ambivalent attitudes experienced; while the more established lead brand had significant impact on the rebranded brand attitude. The lead and partner brands, though

\footnotetext{
* Waseda University Tokyo, Japan(grace@toki.waseda.jp)
} 
both familiar, represented different meanings to consumers. The author attributed these results to the prior parent brand attitudes, the skepticism and their general ambivalence toward the corporate rebranding. Both general attitude factors (i.e. skepticism and general ambivalence towards rebranding) were found to have significant positive impacts on ATR. Skeptical individuals questioned the possibility of a successful rebranding (Chang, 2011) and were more careful with their evaluations toward "too god to be true' or 'made in heaven' pair of companies. The embedded general ambivalent attitudes that people held toward rebranding could be triggered from the associative network by the ambiguous situation (Prislin \& Quellete, 1996). In addition, the ambivalent rebranded brand attitude was found to lower down purchase intention, supporting Hanze (2001), Lavine (2001) and van Harreveld et al. (2009)'s studies. Ambivalent individuals were found to prefer delay decision making by choosing around the mid-ranged points in 'willingness to buy' scale.

The study provides several marketing implications. Ambivalence management is proven to be important to corporate rebranding to minimize the ambivalent attitudes experienced. This could be done by carefully controlling the parent brands-related and general attitude factors. The high ambivalent individuals are less confident with their own conflicted attitudes and are motivated to get rid of the psychological discomfort caused by these conflicted attitudes (Bell \& Esses, 2002; Lau-Gesk, 2005; van Harreveld et al., 2009). They tend to process information more deeply (Jonas et al., 1997; Maio et al., 2000; Wood et al., 1985) and pay more attention to message that provides convincible arguments. Providing strong, favorable and convincible message is hence effective in alleviating consumers' ambivalent attitudes. In addition, brand name heuristic could be utilized because the rebranding strategy sends important signal to consumers about the changes that happen or going to happen. The ambivalent individuals will pay attention to both brand name heuristic and rebranding message in their effort to alleviate the psychological discomfort caused by ambivalent attitudes. The findings also provide insights to Malaysian and airline operators for a better planning and implementation of corporate rebranding exercise.

Key words: Corporate rebranding, ambivalent attitudes, skepticism, purchase intention

Even though ambivalence is a more general and explainable model for various action tendencies (Cacioppo \& Berntson, 1994) that provides explanation for how consumers react to an imposed change (e.g. corporate rebranding), the huge influence of the consistency models of attitudes leaves little room for the existence of conflict that might give rise to ambivalence
(Baek, 2010). It is only in the recent years that the commonly used bipolar semantic differential scale of attitude measurement is challenged by a growing amount of attitude research (Zhao \& Cai, 2008). Attitude researchers have started to recognize that people do simultaneously hold both positive and negative attitudes toward an attitude object. The unipolar 
ambivalence scale not only complements but also enriches the attitude scale by allowing the attitude examination to include indifferent, ambivalent and univalent attitudes (Cacioppo \& Berntson, 1994).

Since then the ambivalence concept has gained attention in psychology (see Cacioppo, Berntson, 1994; Cacioppo, Gardner \& Bernston, 1997; Conner \& Armitage, 2008), political science (see Baek, 2010; Hanze, 2001; Hudson, Maio \& Esses, 2001; Keele \& Wolak, 2008; McGraw, Hasecke \& Conger, 2003; Rudolph \& Popp, 2007), social psychology (see Breckler, 1994; Nordgren, van Harreveld, van der Plight, 2006; Petty, Tormala, Brisnol \& Jarvis, 2006; Priester \& Petty, 1996; 2001; van Harreveld, van der Plight \& de Liver, 2009) and management studies (see Brooks, Highhouse, Rusell \& Mohr, 2003; Oreg \& Sverdlik, 2011; Piderit, 2000; Siomkos, Rao \& Narayanan, 2001; Randall \& Procter, 2008: Sverdlik \& Oreg, 2009). Recently, marketers have also joined in the rush to examine ambivalent attitudes towards various marketing issues and attitude objects (see Chang, 2011; 2012; Chang \& Villegas, 2007; Lau-Gesk, 2005: Nowlis, Kajn \& Dhar, 2002; Priester, Petty \& Park, 2007; Roster \& Richins, 2009; Zemborani \& Johar, 2007). However, few have looked at the potential antecedent factors influencing ambivalent attitudes (Rudolph \& Popp, 2007) and the consequences on behavioural intention in marketing or branding related studies.
In this study, corporate rebranding is presumed to be an imposed change condition which induces ambivalent attitudes toward rebranding (i.e. termed as "ambivalence towards rebranding" in this paper). This proposition is evident in the previous qualitative corporate rebranding studies (e.g. Daly \& Maloney, 2004; Stuart \& Muzellec, 2004) as well as other imposed change studies (see Oberg, Grunstrom \& Johnson, 2011; Oreg \& Sverdlik, 2011; Sverdlik \& Oreg, 2009; Yang, Davis \& Robertson, 2012). When two corporate brands are joined or merged, consumers should be more receptive when the companies are highly established because both brand evaluations are likely to be elicited in addition to certain stored brand-specific associations (Broniarczyk \& Alba, 1994). Established companies are assumed to perform consistently even with the rebranding. However, the truth is, many highly established brands fail in their corporate rebranding efforts (c.f. Lavin, 2009). Organisational studies, for instance, found that familiar companies generally represent larger targets for disparaging information (Brooks et al. 2003) in which consumers hold both positive and negative information through media exposure (Fomburn \& Shanley, 1990). People possess more reasons to work for or against enriched firms (Highhouse, Strierwalt, Bachiochi, Elder \& Fisher, 1999). Similar findings were also found in brand alliance studies (e.g. Lafferty, Goldsmith \& Hult, 2004) where the post attitudes of a familiar 
corporate name were in fact less favourable than their pre-existing attitudes in a causebrand alliance (Lafferty et al., 2004). Hence, this paper presumes that the corporate rebranding between two familiar brands is a double-edged sword which not only raises the expectation for better performance, but also induces more conflicting reactions resulting from consumers' direct and indirect brand experiences (Alba \& Hutchinson, 1987). This would lead to variations in consumers' behavioural intention. The review of the literature also showed that the antecedents and consequences of corporate rebranding have been examined separately, rather than in one single study, causing the findings to be inconclusive. This study aims to fill in the gap in the literature by providing empirical examination on the antecedents as well as the consequences of the ambivalence towards rebranding in one single study.

\section{Antecedents to Ambivalence towards Rebranding}

\subsection{Parent Brand Related Attitudes}

Consumers hold attitudes toward various physical and social objects (including marketing strategies: Peter \& Olson, 2010) and tend to process new information in a manner consistent with their prior opinion (i.e. pre-existing atti- tudes; Judd, Kenny \& Krosnick, 1983). In many cases, prior attitudes serve as anchors in influencing how new information is processed (Sherif \& Hovland, 1961) and closely related to the behavioural intention (Prislin \& Ouellette, 1996). Positive prior experiences are evident in many advertising (Batra \& Ray, 1986; Edell \& Burke, 1986; Gresham \& Shimp, 1985; Messmer, 1979; Thorson \& Page, 1990) and brand alliance studies (Lafferty et al., 2004; Simonin \& Ruth, 1998) to mitigate dissatisfaction. Applying the same concept to corporate rebranding, when consumers are exposed to a rebranding message, their prior attitudes toward the brand will serve as anchors (Sherif \& Hovland, 1961) in affecting their attitudes toward the corporate rebranding exercise. Generally, individuals who possess positive attitudes will form favourable attitude toward rebranding and have a positive evaluation toward the rebranded company (Mazaheri, Basil \& Yanamandram, 2011). Similarly, those who possess negative attitudes and are biased in the information processing process in a direction implied by the valence of those attitudes will act negatively. These are common outcomes in attitudinal studies that consumers could generate a general univalent evaluation of either positive or negative attitudes; people either like or dislike a product/service, without experiencing psychological conflict.

However, the ambivalence theory proposes that these initial attitudes toward the parent 
brands could be mixed (e.g. holding favourable attitudes toward one of the parent brand and unfavourable attitudes toward the other, or holding both favourable and unfavourable attitudes toward the same parent brand) leading to more conflicted reactions (especially in the case of M\&A situation), not only to the newly rebranded brand, but also to the corporate rebranding program. The aforementioned argument posits that familiar companies represent larger disparaging information (Brooks et al., 2003) and brand image is reinforced by borrowing from the higher performance brand (Geylani, Inman \& Ter Hofstede, 2008). Hence, the spilloveer effect is not limited to a positive one. In many cases, the uncertainty associated with the more reliable brand increases as a result of the spilloveer from the less reliable brand to the more reliable one in a corporate rebranding. Consumers are more uncertain about a co-brand product, resulting in higher posterior variance (Geylani et al., 2008) or have doubts about the efficiency of the corporate rebranding (Stanley, Meyer \& Topolynsky, 2005). The large amount of information available for familiar brand could also lead to the transfer of unfavourable ratings to the less familiar or neutral brand. These mixed reactions explain the ambivalent nature of attitudes toward rebranding. In other words, consumers' atitudes toward a single brand could be mixed and ambivalent.

However, the studies examining the prior parent brand attitudes and corporate rebranding issue are scarce. It is not clear how much impact could the prior parent brand attitudes have on rebranded brand attitudes, even for the better researched brand alliance studies (see Lafferty et al., 2004; Simonin \& Ruth, 1998). In corporate rebranding, it is presumed that the underlying mixed attitudes could be activated and contributed separately to affect the attitude towards rebranding, along with other factors such as the disagreement with the rebranding campaign, or choice of partner, or even skepticism about the outcomes of the corporate rebranding. Consumers will experience lower ambivalent attitude when their attitudes toward both parent brands are univalent (i.e. not mixed or conflicted) compared to when these attitudes are mixed (i.e. when the parent brands possess mixed or conflicted evaluations). In addition, the rebranded brand attitude, rather than the post- exposure attitudes of parent brands, should be examined because M\&A-c aused corporate rebranding is an imposed strategic organizational change that affects both companies permanently. Hence, the attitude towards rebranding in this study is measured by an objective ambivalent scale and termed as ambivalence towards rebranding. A similar scale is also adopted to test the prior parent brand attitudes by examining the underlying positive and negative attitude reactions.

Hypothesis 1: Prior parent brand attitudes have significant relationship with Ambivalence 
towards rebranding (ATR).

Hypothesis 1a: Ambivalence towards rebranding (ATR) experienced will be lower when the prior attitudes for both of the parent brands are univalent (positive or negative).

Hypothesis 1b: Ambivalence towards rebranding (ATR) experienced will be higher when the prior attitudes for both of the parent brands are mixed (positive and negative).

In brand alliance studies, the newly formed attitudes toward alliance encompass the assessments and associations for both alliance brands. Knowledge of concepts, experiences and objects are stored in the memory in nodes that are linked together to form associated structures. Equal contributions are expected to the alliance when both brands are familiar; and the brand alliance evaluation will generate a greater spilloveer on the unfamiliar brand, compared to that of the familiar brand (Simonin \& Ruth, 1998). This is caused by the relatively small and currently weak accessibility of the associative network (Fazio, 1986, 1989) of the unfamiliar brand. Consumers have fewer experiences with a less familiar brand, and hence have fewer associations (Campbell \& Keller, 2003) available for information processing.

Similarly, for a repositioned brand, consumers' familiarity toward a brand influences the prior parent brand-rebranded brand attitude's relationship as such: the lower the familiarity, the smaller the effect of prior parent brand atti- tudes on the rebranded brand attitudes and vice versa. This is grounded in the basics of the associative network theory in that attribute information is harder to retrieve and more susceptible to competitive interference for the unfamiliar brand. For the familiar brand, marketing communication claims enhance its memorability and reduce competitive interference (MacInnis, Moorman \& Jawoski, 1991; Moorman, 1990) and hence have stronger influence on the evaluation of the rebranded brand attitude. The rebranded brand attitude is measured by an objective ambivalence scale to reflect the underlying positive and negative evaluations, similar to the ATR and prior parent brand attitudes. In other words, the relationship between RBA and ATR is presumed to be positive. The established associative networks of both brands are more accessible when both parent brand names are highly familiar, and have significant influence on the rebranded brand attitude. Hence,

Hypothesis 1c: Prior attitudes of both parent brands have significant influences on Rebranded Brand Attitude (RBA).

\subsection{General attitudes: Skepticism toward Rebranding and General Ambivalence towards Rebranding}

Skeptical consumers generally form more negative attitudes toward the motives of market- 
ers (Andrews, 1989; Boush, Friestad \& Rose, 1994; Calfee \& Reingold, 1994; Mangleburg \& Bristol, 1998), and question whether a particular change is going to be effective (Stanley et al., 2005). They are also harder to be convinced and persuaded by advertising, show weaker brand beliefs consistent with advertising claims and have different responses to emotional versus informational appeals (Obermiller, Spangenberg \& MacLachlan, 2005). Skeptics are also more careful with 'too good to be true' message that they would be on guard to uncover a hidden and unfamiliar persuasive tactic. This always happens when the ads are difficult to verify, or when there are discrepancies between the ads claims (Folkes 1988; Ford, Smith \& Swasy, 1990; MacKenzie \& Lutz, 1989), or perceived deceptions by marketers (Forehand \& Grier, 2003).

Consumer skepticism is also found to negatively affect consumers' perceptions and attitudes regarding product endorsements, even when the information is neutral (Bailey, 2007). People are less favourable towards the endorsement and the company, perhaps due to perceived deception. As a result, negative reactions to the firm have often ensued (Andreasen, 1996; Ellen, Mohr \& Webb, 2000). People with high skepticism tend to see compelling evidence before believing (Fleming, 2005). In Chang's (2011) study, skepticism predicts ambivalent attitudes, whether the target is green products or buying green products. Consumers feel uncomfortable when viewing advertisements with high effort green claims and hence engage in motivated processing due to the ambivalent attitudes. Hence, in corporate rebranding, consumers who are familiar with the parent brands will question the probability of a successful corporate rebranding, and are more careful with their evaluations toward 'too good to be true' or 'made in heaven' pair of companies. In brief, skepticism causes more ambivalent attitudes toward rebranding.

The formation of general attitudes is based on the recapitulation of the specific attitudes toward each attitude object (Sun \& Wilson, 2008). Hence, the general attitude is helpful in explaining the general tendency to engage in relevant behaviours involving a category of attitude objects (see Ajzen \& Fishbein, 1977; Eagly \& Chaiken, 1993). A general attitude predicts a specific attitude well (Prislin \& Ouellete, 1996) when a specific situation is explicitly related to the general issue and when the general issue is evoked before the specific evaluative reactions.

People start to search for guidance in forming their attitude toward an ambiguous situation, and analyze more to comprehend a situation and become aware of the existence of various elements (Graziano, 1987). Consumers will search for guidance in forming their attitudes toward a specific rebranding when prompted with the rebranding stimulus of a particular case. The embedded general attitude could be 
triggered from the elements in the associative network by this ambiguous situation (Prislin \& Ouellette, 1996) along with other elements, in the effort to form an attitude toward a specific attitude object. The in-depth interviews conducted by Phang's (2012) showed that people tend to have a general attitude towards rebranding which is a separate but related construct to ATR and this attitude is ambivalent in nature. The unipolar or bivalent measurement scale of the general ambivalence towards rebranding allows the underlying positive and negative aspects of the attitude to be measured. The general ambivalence towards rebranding is presumed to have a significant positive relationship with ambivalence towards rebranding in a specific rebranding case.

Hypothesis 3: Skepticism towards rebranding has a significant relationship with ATR experienced.

Hypothesis 4: General ambivalence towards rebranding has a significant relationship with ATR experienced.

\section{Consequences to Ambivalence toward rebranding}

Marketers have widely adopted the understanding of attitude as a significant determinant of behavioural intention (Ajzen \& Fishbein, 1973; Norman, 1975) and posited that brand attitude significantly influences purchase intention (Batra \& Ray, 1986; Brown \& Stayman, 1992; Mackenzie, Lutz \& Belch, 1986; Mitchell \& Olson, 1981; Phelps \& Hoy, 1996; Shimp $\&$ Gresham, 1985). Strong and accessible attitudes facilitate and accelerate decision making (Fazio, Blascovich \& Driscoll, 1992), where a positive attitude will prompt for higher buying intention and a negative attitude will reduce it.

Attitude researchers also posit that people tend to engage in more systematic information processing (Jonas, Diehl \& Bromer, 1997; Maio, Esses \& Bell, 2000) when they hold conflicted attitudes. They will show a weaker relationship between attitude and behaviour (Lavine, 2001) and tend to delay decision making (Lavine, 2001; van Harreveld, van der Plight \& de Live, 2009). The positive and negative reactions held by these individuals will directly influence their attitude towards the rebranded brand and this in turn influences their purchase intention. Individuals might not be able to draw much information about the rebranding which could convince them of promising outcomes. Delaying a purchase decision is hence common for consumers, especially among highly ambivalent individuals. They can only draw information from what they already know about the parent brands, or based on their general attitudes toward rebranding or even their level of skepticism. This ambivalent attitude is thus held with less confidence and is more unstable (Pomerantz, Chaiken \& Tordezillas, 1995) and could put up 
a stop sign (Hanze, 2001) to decision making. It is mentioned in the previous discussion that both ATR and rebranded brand attitude (RBA) are measured with the ambivalence scale causing a negative relationship between ambivalent attitude and behavioral intention. Hence, individuals who experience higher ambivalence towards rebranding will also have higher rebranded brand attitude scores. Consequently, higher ambivalent rebranded brand attitude will cause lower purchase intention.

Hypothesis 5a: ATR has a significant influence on $R B A$.

Hypothesis 5b: RBA will significantly influence Purchase Intention

\section{Methodology}

The hypothesized relationships in this study are integrated into a predictive model (see Figure 1). In this model, ambivalence towards rebranding (ATR) is jointly predicted by the prior parent brand attitudes, skepticism towards rebranding and general ambivalence towards rebranding (GATR). The ATR is then presumed to significantly influence the rebranded brand attitude (RBA) and RBA, in turn, influences purchase intention (PI). The respondents who participated in this study were working adults from different demographic backgrounds and the online survey was conducted over a period of two months. A total of 162 responses were collected and six were discarded due to incompleteness of data; and 156 questionnaires remained usable.

In the preliminary stage, the author conducted five short telephone interviews with five respondents who had no idea of the study objective to find out the suitability of the choice of focal brands. Several pairs of local corporate brands were examined for their level of familiarity and attitudes, including telecommunications, automobile and airlines. Airlines were chosen as the interview results showed that all five respondents possessed both positive and negative attitudes toward both airlines. They also consistently portrayed conflicted reactions when prompted for their attitudes toward rebranding, which reconfirmed the ambivalent attitude proposition. Malaysia Airlines System (MAS), the national air flight carrier served as the lead brand; whereas Asia Asia Berhad (AA), a private-owned carrier, was chosen as the partner brand. These two brands are highly familiar and recognizable local brands in Malaysia.

The questionnaire comprised of two sections. The first section requested the respondents to state their level of prior attitudes toward both parent brands, level of skepticism and general ambivalence towards rebranding. In the second section, participants were randomly assigned to three different rebranding strategy scenarios 
(i.e. Acquirer Dominant [Malaysia Airlines], Joined Name [Malaysia-Air Asia] and Radical Change [TransAlliance] strategies). They were exposed to a news announcement announcing corporate rebranding between MAS and AA (caused by M\&A) and the proposal of a new rebranded name before being asked to rate their ambivalence towards rebranding, rebranded brand attitudes and purchase intention. The test stimuli were standardized in terms of message content across all rebranding strategies, with brief information about rebranding to minimize the message strength effect. Lastly, upon debriefing, respondents were asked to respond to demographic information and a question asking whether they were the current user of either airline.

All the attitude constructs in the present study (prior attitude toward parent brands, ATR, GATR and RBA) were measured using a 7-point six items objective ambivalence scale, with three positive and three negative attitude questions. Objective ambivalence is experienced when people are aware of their conflicted intra-attitude structure, but do not necessarily feel psychological discomfort about it (McGraw et al., 2003). It is only when the potential ambivalence is high and they are asked to make a decision that discomfort will be felt (Newby, Clark, McGregor \& Zanna, 2002). Respondents were asked to rate the positive (negative) aspects by ignoring the negative (positive) aspects for every question (Kaplan, 1972). Thompson et al. (1995)'s formula was adopted in this study $($ AMBIVALENCE $=|(\mathrm{P}+\mathrm{N}) / 2|-|\mathrm{P}-\mathrm{N}|)$ as it is less complex and more closely related to felt ambivalence than any other index (Priester $\&$ Petty, 1996). The ambivalent scores ranged from -6 to 21. High ambivalent individuals are those who hold moderate to high levels of positive and negative attitudes; whereas low ambivalent individuals are those who hold more polarized or univalent attitudes (either positive or negative).

The skepticism construct in the present study measured individuals' skepticism toward corporate rebranding, which includes both doubt about the motives as well as the effectiveness of change. The scale was adopted and refined from Stanley, Meyer and Topolnytsky (2005) and Mohr, Eroglu and Ellen (1998)'s studies. The reliability test with the refined seven item scale produced a Cronbach's alpha coefficient of .940, with correlated item-total correlations ranging from .771 to .864, which indicated adequate reliability (Hair et al., 1998). The Principal Component analysis conducted on the seven items identified one component which explained $73.84 \%$ of the variance. The component matrices ranged from .832 to .904 and the variables were interdependent according to Bartlett's test of sphericity (Bartlett, 1950), X² $(21,156)=875.901, \mathrm{p}<.0001$. The measures for sampling adequacy in anti image covariance analysis were all significant at .05 levels with values ranging from .917 to .945. The KMO 
measure of sampling adequacy (MSA) was .932 (Kaiser, 1970). Correlation test results for all seven items showed positive correlations ranging from .616 to .758 .. The composite reliability calculated for the skepticism construct was 0.952 and AVE value was .738, both above the minimum requirements of 0.6 and 0.5 , hence showed adequate convergent validity (Fornell \& Larker, 1981).

\section{Findings}

Hypothesis 1 presumes a significant relationship between the ambivalence towards rebranding (ATR) and the prior parent brand attitudes. Ambivalence towards rebranding is expected to be lower when the prior attitudes for both the parent brands are univalent (positive or negative) [H1a]; and higher when the prior attitudes for both parent brands are mixed (positive and negative) [H1b]. The prior atti- tude scales in this study were measured by an objective ambivalence scale in which high attitude scores indicated high ambivalent attitudes. The multiple regression test was conducted to test Hypothesis 1 with four independent variables (i.e. prior attitudes for AA, prior attitudes for MAS, skepticism and general ambivalence towards rebranding) on ATR. The results in Table 1 produced a $R^{2}$ value of .855 and $R^{2}$ change value of .851 . The standardized beta coefficients for the link between the prior attitude for AA to ATR were $.112(\mathrm{p}<0.001)$ and 0.025 between the prior attitude for MAS to $\operatorname{ATR}(p=.546)$. In other words, the notion that the prior parent brand attitudes will significantly influence ATR only works in the case of AA but not for MAS, which only partially supported Hypothesis 1.

To test Hypothesis $1 \mathrm{a}$ and $1 \mathrm{~b}$, the prior attitudes for Malaysia Airlines (MAS) and AirAsia (AA) were combined and grouped into high and low groups, with median splits. Two dummy variables were then created for MAS and

〈Table 1〉 Multiple regression analysis on the antecedent factors on ATR

\begin{tabular}{|c|c|c|c|c|}
\hline Independent Variable & Mean & Standardised $\beta$ & $\mathrm{t}$ & Sig. \\
\hline (constant) & & & -6.129 & .000 \\
\hline Ambi AA & 6.891 & .112 & 2.946 & .004 \\
\hline Ambi MAS & 6.9359 & .025 & .612 & .542 \\
\hline Skepticism & 4.6181 & .378 & 9.583 & .000 \\
\hline General ATR & 10.4202 & .561 & 11.794 & .000 \\
\hline Model Fit & \multicolumn{2}{|c|}{$F$ change $=222.474(p=.0001)$} & & \\
\hline & $\mathrm{R}^{2}=.855$ & AdjustedR $^{2}=.851$ & & \\
\hline
\end{tabular}

a. Dependent variable: Ambivalence towards rebranding 
AA (e.g. $1=$ high ambivalent group; $0=$ low ambivalent group). A third dummy variable (i.e. PriorParent) was created to compare and combine these two dummies. In brief, a respondent with a score of 1 for MAS and 1 for AA or with a score of 1 for either of the corporate brands would be considered as mixed attitude'; and considered as 'univalent' when both parent brand scores were 0 in this PriorParent dummy. The one way between group ANOVA results in the second row of Table 2 showed that the group with univalent parent brand attitudes and the group with mixed parent attitudes were significantly different $(F(1,156)$ $=171$. 339, $\mathrm{p}<.0001)$. In other words, when the parent brand attitudes were univalent, lower ATR would be experienced compared to when the parent brand attitudes were mixed. These results supported both Hypothesis $1 \mathrm{a}$ and $1 \mathrm{~b}$.

Nevertheless, the above examination did not consider the issue when consumer experienced inter-brand ambivalence rather than intradimension ambivalence. In other words, consumers not only felt ambivalent within the MAS or AA brands, they could also felt ambivalence when they hold univalent but con- tradict attitudes toward both parent brands (e.g. one with positive and the other with negative attitude). A one-way between group ANOVA test was carried to examine consumers' response to this situation. Respondents were first grouped for their respective attitudes toward both parent brands ( $1=$ positive dominant attitude; $2=$ negative dominant attitude; $0=$ ambivalent attitude) and a dummy called Parent Brand Domination was created ( $1=$ both parent brands were in conflict; $0=$ both were not in conflict). The third row of Table 2 below showed significant differences between these two groups for low ambivalent individuals, F(1, $75)=116.264, \mathrm{p}<.0001$ and the eta square value of 0.61 showed large effect size. The consumers experienced less ambivalence when both brand attitudes were not in conflict (e.g. positive and positive, negative and negative) compared to when they were in conflict (e.g. one positive and the other negative). A significant difference was also found in the result of the one way between group ANOVA result for Parent Brand Domination on rebranded brand attitude (RBA), $\mathrm{F}(1,75)=96.807, \mathrm{p}<.0001$ (refer to Table 3).

〈Table 2〉 One-way between group ANOVA tests for Prior Brand and Parent Brand Domination on Ambivalence towards rebranding

\begin{tabular}{|l|c|c|c|c|c|c|}
\hline \multicolumn{1}{|c|}{ Independent variable } & $\mathrm{N}$ & Sum of squares & $\mathrm{df}$ & Mean square & $\mathrm{F}$ & Sig. \\
\hline Prior Brand & 155 & 2546.573 & 1 & 2546.573 & 171.339 & .000 \\
\hline Parent Brand Domination & 75 & 1201.328 & 1 & 1201.328 & 116.264 & .000 \\
\hline
\end{tabular}

a. Dependent variable: Ambivalence towards rebranding 
〈Table 3〉 One-way between group ANOVA tests for Parent Brand Domination on Rebranded Brand Attitude

\begin{tabular}{|l|c|c|c|c|c|c|}
\hline \multicolumn{1}{|c|}{ Independent variable } & $\mathrm{N}$ & Sum of squares & $\mathrm{df}$ & Mean square & $\mathrm{F}$ & Sig. \\
\hline Prior Brand & 155 & 2546.573 & 1 & 2546.573 & 171.339 & .000 \\
\hline Parent Brand Domination & 75 & 1411.558 & 1 & 14.581 & 96.807 & .000 \\
\hline
\end{tabular}

a. Dependent variable: Rebranded brand attitude

Hypothesis 1c presumes that the prior parent brand attitudes have significant positive influence on the RBA. The path model was tested with SmartPLS software due to the small sample size consideration (i.e. 156 respondents; Hair, Ringle \& Sarstedt, 2011). According to Hair et al. (2011), PLS-SEM is a more 'regression based' approach which minimizes the residual variance of the endogenous constructs and does not presume the normal distribution of the data. Consequently, PLS-SEM applies nonparametric bootstrapping (Davison \& Hinkey, 1997; Efron \& Tibshirani, 1993 in Hair et al., 2011) in obtaining standard errors for hypothesis testing and enables the estimated coefficients to be tested for their significance (Henseler, Ringle \& Sinkovics, 2009 in Hair et al., 2011). The significance of the path model relationships is performed by examining the $t$-values of each relationship. Figure 1 below shows the t-values for all the relationships in the path model.

The findings only supported the hypothesis in the case of MAS ( $t=3$. 911) but not for AA. The link between the prior attitude for AA to RBA did not achieve statistical significance $(t=1$. 479). Hence, H1c is not fully supported. The path model also shows several interesting findings. The link between the prior attitude for MAS and ATR was found not to achieve statistical significance $(t=.606)$; whilst it was statistically significant for the link between prior attitude for AA to ATR $(t=2$. 880). These results are consistent with the multiple regression analysis results showed in Table 1.

Hypothesis 2 posits a positive relationship between the skepticism toward rebranding and ATR. The bootstrapping results in Figure 1 showed a t-value of 9.627 which supported the proposed hypothesis. Hypothesis 3 is also supported with a significant relationship between the General ambivalence towards rebranding (GATR) and ATR $(t=8$. 844). These results also showed that the GATR had a larger influence on ATR compared to skepticism. The path model results were consistent with the multiple regression analysis in Table 1 that the standardized beta coefficient for the skepticism-ATR was .378 and .501 between GATR and ATR (ps < .0001). The part correlation coefficient value was .366 for GATR and .297 for skepticism, which meant GATR explained around $13.39 \%$ and skepticism for $8.82 \%$ of the variance in ATR. 
〈Figure 1〉 Path Model for antecedents to and consequences of ambivalence towards rebranding

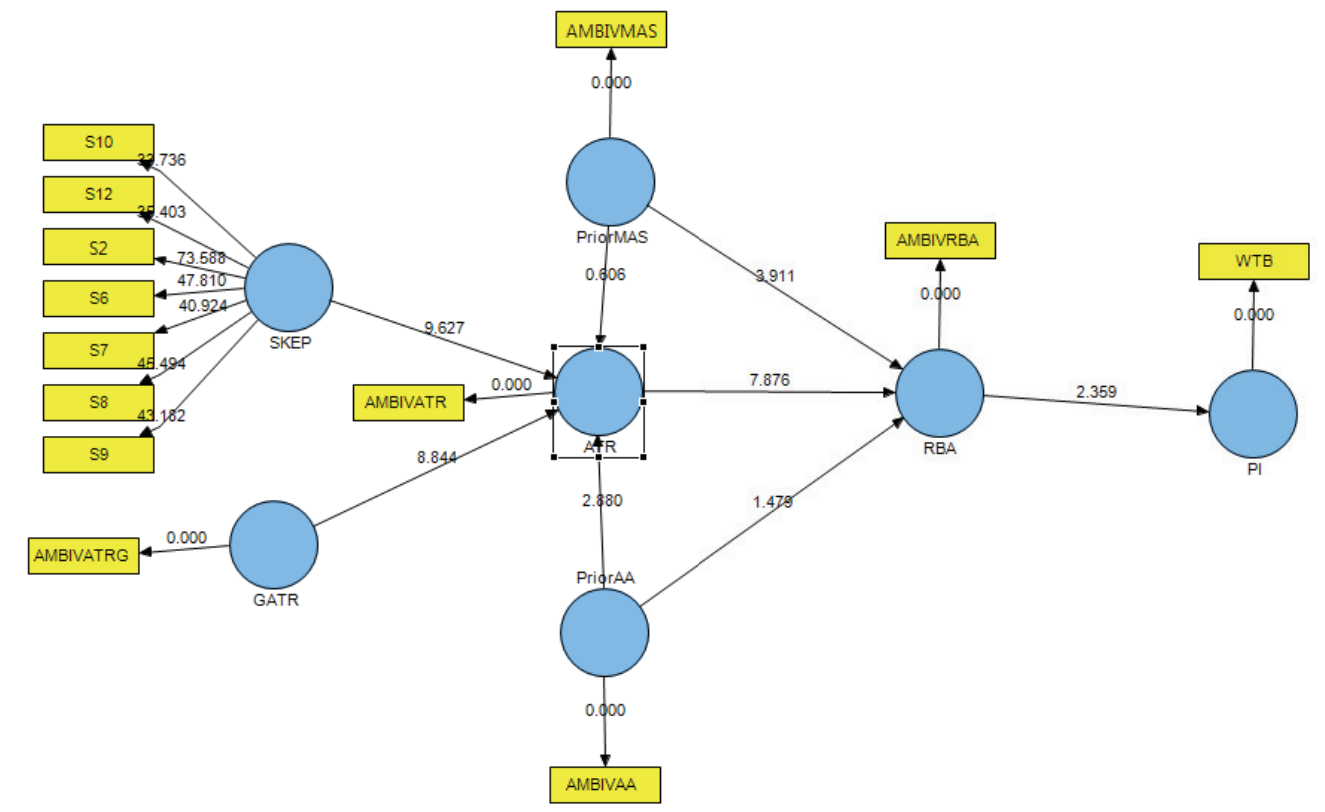

Hypothesis 5 examines the consequence of intention.

ATR on RBA, which in turn affects purchase intention (PI). The path model in Figure 1 confirmed the relationships between ATR-RBA [H5a] and RBA-PI [H5b], with $t=7.876$ for

\section{Discussion}

the former link and $t=2.359$ for the latter. The path coefficient mean values for the link between ATR and RBA was .599 and -.236 between the RBA and PI, which further supported $\mathrm{H} 5 \mathrm{a}$ and $5 \mathrm{~b}$. As mentioned before, the relationship between the RBA and PI was expected to be negative because the RBA construct was measured by an objective ambivalence scale which reflected the ambivalent attitude experienced toward the rebranded brand. Consequently, a high RBA represents high ambivalent attitudes and causes lower purchase

Marketing communication claims are effective to enhance the memorability of brands and reduce competitive interference (MacInnis et al., 1991; Moorman, 1990), which in turn will have a strong influence on the evaluation of rebranded brand attitude. When both parent brand names are highly familiar, consumers will be able to assess the established associative networks of both brands, causing the prior attitudes to play significant influence on $\mathrm{re}^{-}$ branded brand attitude. The findings of this 
study seconded this assumption whereby a significant relationship was found between the prior attitude for Air Asia (AA) and ATR (Ambivalence towards rebranding). However, there was no significant relationship found between the prior attitude for Malaysia Airlines (MAS) and ATR. Conversely, the prior attitude for MAS was found to be significantly linked to RBA; whilst the prior attitude for AA was not. These results do not support the previous brand alliance study (e.g. Simonin \& Ruth, 1998) in that the prior attitudes of the parent brands should have significant influence on both the attitude towards alliance and post exposure attitudes. The results also do not second the brand alliance studies in that familiar parent brands will contribute equally to the attitude towards alliance (Simonin \& Ruth, 1998).

The difference between the brand alliance literature and the present study could be due to several reasons. First of all, corporate rebranding is fundamentally different from a brand alliance. The brand alliance studies generally study the impacts of pre-existing attitudes on the post exposure attitudes, without examining the alliance brand attitude; and both alliance companies are still viewed as separate entities even after the alliance. In corporate rebranding, it is the imposed change that causes mixed consumers' reactions (Phang, 2012). The corporate name change is the most frequently applied strategy and normally utilised as a signal for corporate changes (Jaju, Joiner
\& Reddy, 2006). This corporate rebranding decision is irreversible and permanent; hence it is reasonable to examine the impacts of corporate rebranding on the rebranded brand attitude (RBA). Furthermore, the rationale to study the rebranded brand attitude is also caused by the length and scope of an alliance which might not be long term and strategic in nature, compared to that of a corporate rebranding.

In addition, the imposed change proposition presumes the evaluation of the underlying consumer attitudes to reflect both positive and negative reactions. For instance, consumers could form an overall positive or negative evaluation of a company when they hold: a) no negative (positive) evaluation at all, or $\mathrm{b}$ ) the positive (negative) evaluations dominant over the negative (positive) evaluations, and results in overall positive (negative) evaluation. The imposed change proposition presumes that when the change is involuntary, "the opportunity for novelty is combined with a restriction, rather than promotion, of one's personal autonomy and the right of expression' (Sverdlik \& Oreg, 2009). Corporate rebranding is normally done in a top down manner and consumers are generally neither informed nor consulted before the change (c.f. Lomax \& Mador, 2006). In addition, the original parent brands are expected to be discontinued and permanently changed in a corporate rebranding. These could have induced more ambivalent attitudes and contributed to the differences in findings between the two 
studies. This also provides the rationale to adopt objective ambivalence scale in measuring consumers' attitude towards rebranding (i.e. termed as "ambivalence towards rebranding" in this study), rather than a univalent attitude scale. The results of this study showed that individuals not only experience more ambivalence when they encounter interbrand conflict (e.g. prefer one brand and dislike the other); but also when intra brand conflicts occur (i.e. like and dislike the same brand).

The findings also showed that the consumers depended more on MAS in forming their RBA compared to AA, even though both were familiar brands. Generally, driven by a large amount of information available, consumers might depend more on the processing of the parent brand that they are more familiar with (Abdulmajid, 2011; Machleit \& Wilson, 1988). In advertising studies for instance, Machleit and Wilson (1988) posited a contradictory view of the insignificant relationship between brand attitude and attitude towards advertising for familiar brands in which prior brand attitude is found to have a bigger role than attitude towards advertising (Phelps \& Thorson, 1991) in influencing post exposure brand attitude. According to Machleit and Wilson, the more knowledgeable people are about a certain brand, the lesser they will rely on advertisement to form a brand attitude. Similar results are obtained by Abdulmajid (2011) who studied consumers' attitudes toward print ads. Attitudes toward advertising are found to have an insignificant impact on brand attitudes when the prior attitudes were high.

However, in this study, the role played by ATR was found to have a larger influence on RBA compared to both the prior parent brand attitudes. A possible explanation for these findings could be caused by the choice of the focal corporate brands in this study. Malaysia Airlines which is the flagship airline in Malaysia, has a long history and establishment, even before the country gained independence in 1957. The airline began as Malayan Airlines in 1947 and was later changed to Malaysia-Singapore Airlines. The airline ceased its services in 1972 due to the splitting of Malaysia Airlines and Singapore Airlines and was later renamed as Malaysia Airlines. In 1985, Malaysia Airlines was named Malaysia Airlines System (MAS) until today. Even though the airline has gone through several corporate rebranding exercises and unprofitable years, MAS has remained the only national airline and won many international awards, including the Airlines of the Year by Skytrax in the years 2012, 2010 and 2009 (World Airline Award, 2012). The MAS brand name has a special meaning to Malaysians and they experience lesser ambivalence this national brand in the present study. Consequently, these long established prior attitudes are referred more when forming the RBA, rather than when forming their ambivalence towards rebranding.

The partner brand, AirAsia Berhad, is named 
the world's best low cost airline for the fifth consecutive year by World Airline Award (World Airline Award, 2013). Air Asia is well-known for its innovative branding and joint venture strategies (Poon \& Waring, 2010) and frequently uses press relations to stir up media and public attention. For instance, a charity flight from Perth to Kuala Lumpur was served by Sir Richard Branson, the CEO of Virgin Atlantic, in a red Air Asia skirt after losing a bet to Tony Fernandes, COE of AA in a GrandPrix tournament in 2010 (Air Asia Berhad, 2013). At the same time, AA is also frequently criticized for frequent flight delays and cancellations (Flightstats.com, 2013a, b). A formal protest by more than 20 disabled and wheelchairbound members of the Barrier-Free Environment and Accessible Transport Group (BEAT) in the year 2007 was filed for discrimination against disabled and led to negative publicity for AA (The Star Online, 2007). Hence, it is not surprising that people hold more positive (e.g. world's best low cost airline) and negative information (e.g. delayed flights) toward this airline, causing a significant direct influence of prior attitude of AA on ATR and an indirect influence on RBA through ATR. The earlier assumption by the alliance researchers and the author that the two highly familiar corporate brands can contribute equally to the rebranding is less logical. Familiarity is subjective and can be accessed from various aspects. In this study, MAS and AA represent different types of familiarity and images causing variations in their contributions to the corporate rebranding exercise.

The final part of the path model showed that the ATR significantly influenced RBA and RBA, and in turn affected purchase intention (PI). The findings also showed a larger influence of ATR on RBA, compared to the influence from both prior parent brand attitudes, with a larger beta coefficient value. A possible explanation for this could be referred to the explanation on the choice of the focal brands in this study (i.e. a national airline and a highly successful private owned airline) that causes the variation in the result and induces more significant influence of ATR on RBA. Consumers are ambivalent towards the merger between the national airline and the most successful local low cost airline. They might be skeptical whether corporate rebranding will be successful, considering how different the two companies are, especially when both companies have tried to engage in a share swap deal which was called off eight months after its first announcement in October 2011 (Bernama, 2012). According to Bernama, the cross-holding of shares was intended to better align the economic interests on the part of the major shareholders of MAS (Khazanah) and AirAsia (Tune Air), but had failed to get support from the stakeholders. This unsuccessful share swap deal could lead to higher skepticism about the possibility of a successful rebranding. Worries over 
the tarnishment of the 'high quality' image of MAS as well as concerns over the loss in efficiency of AA could be the other reasons. In addition, consumers might refuse to buy into the idea of 'market domination' when both major airlines are combined. The underlying positive and negative reactions could be activated and contributed separately to affect ambivalence towards corporate rebranding. The findings also showed both direct and indirect influences of ATR on PI, proven by a significant link between ATR to PI $(t=2.385)$ as well as via RBA $(t=7.876)$. This result supported the previous studies by Hanze (2001) and Jonas et al. (1997) in that an ambivalent attitude could have a direct influence on behaviour intention.

The above proposition is also supported by the significant links between skepticism and general ambivalence towards rebranding. Both general attitudes were found to affect ambivalence towards rebranding, which tallied with Chang's (2011) study on consumers' willingness to buy green products. Consumers feel uncomfortable when viewing advertisements with high effort green claims and engage in motivated processing due to ambivalent attitudes. The present study shows that customers might question the probability of a successful rebranding, and be more careful in their evaluations toward 'too good to be true' or 'made in heaven' pair of companies. High skepticism will cause more ambivalent attitudes to be formed. In fact, the path model and the multiple re- gression analysis provided statistical proof that general ambivalence towards rebranding is important contributor to ambivalence towards rebranding. As this general attitude does not specifically refer to a particular rebranding case, it contains any information which could be both positive and negative and formed from various sources (e.g. news announcements in books, articles, newspapers or even television; their own previous experiences; or hearsay from relatives and friends about rebranding issues).

\section{Implications, Limitations and Conclusion}

The present study provides several marketing implications. First of all, both parent brand-related and general (skepticism and general ambivalence toward rebranding) attitudes have significant influences on ambivalence towards rebranding. Marketers need to consider these relevant factors in planning for their corporate rebranding. They can minimize the ambivalent attitudes people hold toward rebranding by carefully controlling these antecedent factors. Ambivalence management is critical because ambivalent individuals were found to prefer to choose around mid range points for their willingness to buy the rebranded brand. In another words, these ambivalent individuals tend to delay their buying to an unknown future, which 
is an unfavorable situation to marketers.

Secondly, the findings also showed that familiar brands could mean different things to consumers. In this study, the lead brand (Malaysia Airlines) has more special meaning or sentimental value to their consumers and lead to significant influence on rebranded brand attitudes. Consumers only depend on one side of the information (i.e. more positive information in the present study) even though they held mixed prior brand attitudes. Conversely, people who hold more positive and negative underlying evaluations toward the partner brand that could lead to higher ambivalence towards rebranding. Individuals were also found to $\mathrm{ex}^{-}$ perience higher ambivalent when their attitudes toward both brands were in conflict.

To alleviate the ambivalent attitudes, marketers could build on promoting the positive aspects or advantages of the corporate rebranding using appropriate marketing tools. The high ambivalent attitudes experienced cause the individuals to be less confident with their own attitude, process new information more deeply (Wood, Kallgren \& Priesler, 1985) and become motivated to get rid of the uncomfortable conflicted states (Bell \& Esses, 2002; Lau-Gesk, 2005; van Harreveld et al., 2009). They pay more attention to strong and favourable message that strongly promotes the corporate rebranding and useful in alleviating their ambivalent attitudes. This could be disastrous when managers sometimes ignore the importance of message arguments in reducing resistance to change (Amernakis \& Harris, 2002), and lead to unsuccessful change management.

In addition to the message arguments, marketers could utilize brand name heuristics as it is a useful heuristic for quality and used by consumers in preference formation (Gunasti \& Ross, 2010). High ambivalent attitudes could lead to more biased/motivated information processing whereby the brand name heuristic will bias the systematic processing of the information (Gunasti \& Ross, 2010). Maheswaren, MacKie and Chaiken (1992) found that people tend to use both heuristic and systematic processing when assessing important tasks. Air freight is generally considered as more expensive mode of transportation in Malaysia compared to land and sea transportations. Consumers, especially those who are ambivalent, might tend to consider more information in making buying decisions for air freight services, which leads to more biased/motivated information processing. These high ambivalent individuals will tend to be less swayed by the brand name heuristic alone, especially when the message arguments are weak and do not provide solid reasons to convince them (Jonas et al., 1997). Hence, a strong message and suitable corporate name should work well to alleviate ambivalence toward rebranding.

There are several limitations to this study. The study only examined consumers' willingness to buy the rebranded brand, by limiting 
the choice to 'buy' and 'not buy'. However, consumers' choice task options might not be that simple. It is common for people to hold their purchase decision (Dhar \& Kim, 2007), especially when they face difficulty in choosing (Hanze, 2001). Hence, future studies should include the 'hold' option and extend consumers' choice options to "buy the rebranded brand, 'buy other brands' and 'hold the buying' to reflect a more realistic buying situation. This study also did not examine how consumers could have resolved their ambivalence towards rebranding. Ambivalence is an uncomfortable state which consumers are prompted to alleviate the uncomfortable feelings (Maio, Bell \& Esses, 1996). They normally engage in more information searching or amplified information searching (Bell \& Esses, 2002) by hoping that more information will assist them to choose which side of the attitude reactions to rely on. Hence, it is more meaningful for future studies to look into the ambivalence coping strategy and the marketing variables which could be effectively used to alleviate ambivalence towards rebranding. In addition, the choice of the focal brands in this study has also influenced the results of this study. The 'share swap deal' between both companies could have impacts on the ambivalent attitude experienced, which is not expected in the original hypothesis. Nevertheless, the findings provide useful insights to Malaysian marketers and airline operators on the rebranding scenario involving a national airline. The findings also present an interesting issue to study how consumers could have reacted to corporate rebranding for companies that have undergone unsuccessful or doubtful rebranding experiences; or between companies that have a close partnership prior to the corporate rebranding. Future studies should include more corporate brand names to enhance the generalizability of the study. The pretest utilized only five respondents might be not conclusive and the future study should endorse a larger sample size. Nevertheless, airline companies clearly recorded higher familiarity and conflicted ambivalent attitudes than the other two industries in the pretest.

In conclusion, this study provides a comprehensive empirical examination on consumer reactions to corporate rebranding. The shift in consumer preferences has proven to lead to brand revitalization and rebranding (Shin \& Cha, 2013). The findings provide important indications to marketers on factors affecting the ambivalence towards rebranding as well as the consequences on rebranded brand attitude and purchase intention. The recent acquisition of the Nokia mobile phone business by Microsoft implies more corporate rebranding cases to come, and hence corporate rebranding studies are urgently needed to provide a better understanding to this risky and costly organizational change.

〈Received October 11. 2013〉 〈Revised December 15. 2013〉 〈Accepted December 27. 2013〉 


\section{References}

Abdulmajid Sallam, M. A. (2011). The impact of source credibility on Saudi consumer's attitude toward print advertisement: The moderating role of brand familiarity. International Journal of Marketing Studies, 3 (4), 63-77.

Andreasen, A. R. (1996). Profits for nonprofits: Find a corporate partner. Harvard Business Review, 74(6), 47-59.

Airasia.com (2013, April 18). 'Stewardess' Branson to finally serve on AirAsia X flight [press release]. Retrieved on $9^{\text {th }}$ August 2013 from http://www.airasia.com/my/en/press-releases/ branson-to-finally-serve-on-airasia-x-flight. page

Ajzen, I., \& Fishbein, M. (1973). Attitudinal and normative variables as predictors of specific behaviors. Journal of Personality and Social Psychology, 27, 41-57.

Ajzen, I., \& Fishbein, M. (1977). Attitudebehavior relations: a theoretical analysis and review of empirical research. Psychological Bulletin, 84(5), 888-918.

Alba, J. W. \& J. W. Hutchinson (1987). Dimensions of Consumer expertise. Journal of Consumer Research, 13: 411-454.

Andrews, J. C. (1989). The dimensionality of beliefs toward advertising in general. Journal of Advertising, 18(1), 26-35.

Armenakis, A. A. and S. G. Harris (2002).
"Crafting a change message to create transformational readiness." Journal of Organizational Change Management, 15(2), 169-183.

Baek, Y. M. (2010). An integrative model of ambivalence. The Social Science Journal, 47: 609-629.

Bailey, A. A. (2007). Public information and consumer skepticism effects on celebrity endorsements: studies among young consumers. Journal of Marketing Communications, 13(2), 85-107.

Bartlett, M. S. (1950). Tests of significance in Factor Analysis. British Journal of Statistical Psychology, 3(January), 77085.

Batra, R. \& M. L. Ray (1986). Affective responses mediating acceptance of advertising. Journal of Consumer Research, 13: 234249.

Bell, D. W., \& Esses, V. M. (2002). Ambivalence and response amplification: A motivational perspective. Personality and Social PSychology Bulletin, 28, 1143-1152.

Bernama (2012, May 2). MAS-AirAsia swap deal is off. News Strait Times. Retrieved 10th August 2013 from http://www.nst. com.my/latest/mas-airasia-swap-deal-isoff-1.79952 \#ixzz2bZZS8yEB

Boush, D. M., Friestad, M., \& Rose, G. M. (1994). Adolescent skepticism toward TV advertising and knowledge of advertiser tactics. Journal of consumer Research, 21, 1165-1176. 
Breckler, S. J. (1994). A comparison of numerical indexes for measuring attitude ambivalence. Educational \& Psychological Measurement, 54: 350-365.

Broniarczyk, S. M. and J. W. Alba (1994). The importance of brand in brand $\mathrm{ex}^{-}$ tension. Journal of Marketing Research, 31: 214-228.

Brooks, M. E., Highhosue, S., Russell, S. S., \& Mohr, D. C. (2003). Familiarity, ambivalence, and firm reputation: Is corporate fame a double-edged sword? Journal of Applied Psychology, 88(5), 904-914.

Brown, S. P., \& Stayman, D. M. (1992). Antecedents and consequents of altitude toward the ad: a meta-analysis. Journal of Consumer Research, 19(June), 34-51.

Cacioppo, J. T. \& G. G. Berntson (1994). Relationship between attitudes and evaluative space: A critical review, with emphasis on the separability of positive and negative substrates. Psychological Bulletin, 115(3): 401-423.

Cacioppo, J. T., Gartner, W. L., \& Berntson, G. G. (1997). Beyond bipolar conceptualizations and measures: the case of attitudes and evalautive space. Personality and Social Pyschology Review, 1(1), 3-25.

Calfee, J. E., \& Reingold, D. J. (1994). The 70\% majority: Enduring consumer beliefs about advertising. Journal of Public Policy \& Marketing, 13, 228-238.

Campbell, M. C., \& Keller, K. L. (2003).
Brand familiarity and advertising repetition effects. Journal of Consumer Research, 30 (September), 292-303.

Chang, C. C. (2011). Feeling ambivalent about going green implications for green advertising processing. Journal of Advertising, $40(4): 19-31$.

Chang, C. C. (2012). Ambivalent attitudes in a communication process: An integrated model. Human Communication Research, 38: 332359.

Chang, H. J. \& J. Villegas (2007). Consumer responses to advertising on the internet: The effect of individual difference on ambivalence and avoidance. CyberPsychology \& Behvaior, 10(2): 258-266.

Conner, M. \& C. J. Armitage (2008). Attitudinal ambivalence. Attitudes and attitude change. Frontiers of social psychology. W. D. Crano and R. Prislin. NY:US, Psychology Press: 261-286.

Daly, A., \& Moloney, D. (2004). Managing corporate rebranding. Irish Marketing Review, 17(1/2), 30-36.

Dhar, R., \& Kim, E. Y. (2007). Seeing the forest or the trees: Implications of construal level theory for consumer choice. Journal of Consumer Psychology, 17(2), 96-100.

Eagly, A. H., \& Chaiken, S. (1993). The psychology of attitudes. New York: Harcourt BraceJovanovich.

Edell, J. A. \& M. C. Burke (1986). The relative impact of prior brand attitude and 
attitude toward the ad on brand attitude after ad exposure. Advertising and Consumer Psychology. J. Olson and K. Stentis. 3: 93-107.

Ellen, P. S., Mohr, L. A., \& Webb, D. J. (2000). Charitable programs and the retailer: do they mix? Journal of Retailing, 76(3), 393-406.

Fazio, R. H. (1986). How do attitudes guide behavior? The Handbook of Motivation and Cognition : Foundations for Social Behavior. M. Sorrentino and E. T. Higgins. New York, Guilford Press.

Fazio, R. H. (1989). On the power and functionality of attitudes: the role of attitude accessibility. Hillsdale, NJ Lawrence Erlbaum Associates.

Fazio, R. H., Blascovich, J., \& Driscoll, D. M. (1992). On the functional value of attitudes: The influence of accessible attitudes upon the ease and quality of decision making. Personality and Social Psychology Bulletin, 18, 388-401.

Fleming, P. (2005). Metaphors of resistance. Management Communication Quarterly, 19 (1), 45-66.

Flightstats (2013a). On time performance summary from June first to July 31- Airasia Indonesia. Retrieved on $9^{\text {th }}$ August 2013 from http://www.flightstats.com/go/Flight Rating/flightRatingByCarrier.do?airlineCode $=\mathrm{QZ}$

Flightstats (2013b). On time performance sum- mary from June 1 to July 31- Airasia. 78\% Retrieved on $9^{\text {th }}$ August 2013 from http://www.flightstats.com/go/FlightRating /flightRatingByCarrier.do; jsessionid = $5 \mathrm{BA} 1$ BFB4989516A2262486C5B5AF598A.web1: 8009? airline $=\% 28 \mathrm{AK} \% 29+$ Air Asia $\& \mathrm{x}=13$ $\& y=9$

Folkes, V. S. (1988). The availability heuristic and perceived risk. Journal of Consumer Research, 15(June), 13-23.

Fomburn, C. \& M. Shanley (1990). What's in a name? Reputation building and corporate strategy. Academy of Management Journal 333: 233-258.

Ford, G. T., Smith, D. B., \& Swasy, J. L. (1990). Consumer skepticism of advertising claims: Testing hypotheses from economics of information. Journal of Consumer Research, 16, 433-441.

Forehand, M. R., \& Grier, S. (2003). When is honesty the best policy? The effect of stated company intent on consumer skepticism. Journal of Consumer Psychology 13(3), 349-356.

Fornell, C., \& Larcker, D. F. (1981). Evaluating structural equation models with unobservable variables and measurement error. Journal of Marketing Research, XVIII (February), 39-50.

Geylani, T., Inman, J. J., \& TerHofstede. (2008). Image reinforcement or impairment: The effects of co-branding on attribute uncertainty. Marketing Science, 27(4), 730-744. 
Graziano, W. (1987). Lost in the thought at the choice point: Cognition, context, and equality. In J. C. Masters \& W. P. Smith (Eds.), Social comparisons, social jsutice, and relative deprivation: Theoreticla, empirical, and policy perspectives (pp. 265294). Hillsdale, N.J.: Lawrence Erlbaum.

Gresham, L. G. \& T. A. Shimp (1985). Attitude toward the advertisement and brand attitudes: A classical conditioning perspective. Journal of Advertising, 14(1): 10-17.

Gunasti, K., \& Ross, W. T. (2010). How and when aphanumeric brand names afffect consmer preferences. Journal of Marketing Research, XLVII(Dec), 1177-1192.

Hair, J. F., Anderson, R. E., Tatham, R. L., \& Black, W. C. (1998). Multivariate data analysis (5th ed.). Upper Saddle River, NJ: Prentice Hall.

Hair, J. F., Ringle, C. M., \& Sarstedt, M. (2011). PLS-SEM:indeed a silver bullet. Journal of Marketing Theory and Practice, 19(2), 139-151.

Hanze, M. (2001). Ambivalence, conflict, and decision making: attitudes and feelings in Germany towards NATO's military intervention in the Kosovo war. European Journal of Psychology, 31: 693-706.

Highhouse, S., Stierwalt, S. L., Bachiochi, P., Elder, A. E., \& Fisher, G. (1999). Effects of advertised human resource management practices Personnel Psychology, 52(2), 425442.
Hudson, G., Maio, G. R., \& Esses, V. M. (2001). The role of attitudinal ambivalence in susceptibility to consensus information. Basic and Applied Social Psychology, 23 (3), 197-205.

Jaju, A., C. Joiner, et al. (2006). Consumer evaluations of corporate brand deployments. Journal of the Academy of Marketing Science, 34(2), 206-215.

Jonas, K., Diehl, M., \& Bromer, P. (1997). Effects of attitudinal ambivalence on information processing and attitude-intention consistency. Journal of Experiemental Social Psychology, 33, 190-210.

Judd, C. M., Kenny, D. A., \& Krosnick, J. A. (1983). Judging the positions of political candidates. Models of assimilation and contrast. Journal of Personality and Social Psychology, 44, 953-963.

Kaiser, H. (1970). A second generation Little Jiffy. Psychometrika, 35, 401-415.

Kaplan, K. J. (1972). On the ambivalenceindifference problem in attitude theory and measurement: A suggested modification of the semantic differential technique. Psychological Bulletin, 77, 361-372.

Keele, L. \& J. Wolak (2008). Contextual Sources of Ambivalence. Political Psychology, 29 (5) : 653-675.

Lafferty, B. A., R. E. Goldsmith, et al. (2004). The impact of the alliance on the partners: a look at cause brand alliance. Psychology \& Marketing, 21(7): 509-531. 
Lau-Gesk, L. (2005). Understanding consumer evaluations of mixed affective experiences. Journal of Consumer Behaviour, 32: 23-28. Lavin, M. (2009). Marshall Field's becomes Macy's: understanding retail brand. International Journal of Retail \& Distribution Management, 37(11) : 993-1007.

Lavine, H. (2001). The electoral consequences of ambivalence toward presidential candidates. American Journal of Political Science, 45(4), 915-929.

Lomax, W., \& Mador, M. (2006). Corporate rebranding: From normative models to knowledge management. Brand Management, 14(1/2), 82-95.

Machleit, K. A., \& Wilson, R. D. (1988). Emotional feelings and attitude toward the advertisement: The roles of brand familiarity and repetition. Journal of Advertising, 17(3), 27-35.

Maclnnis, D., Moorman, C., \& Jaworski, B. (1991). Enhancing and measuring consumers' motivation, opportunity, and ability to process brand information from ads. Journal of Marketing, 55(October), 32-53.

MacKenzie, S. B., \& Lutz, R. J. (1989). An empirical examination of the structural antecedents of attitude toward the ad in an advertising pretesting context Journat of Marketing, 53(April), 48-65.

MacKenzie, S. B., Lutz, R. J., \& Belch, G. E. (1986). The role of attitude toward the ad as a mediator of advertising effectiveness:
A test of competing explanation. Journal of Marketing Research, XXIII(May), 130143.

Maheswaran, D., Mackie, D. M., \& Chaiken, S. (1992). Brand name as a heuristic cue: The effects of task importance and expectancy confirmation on consumer judgment. Journal of Consumer Psychology, 1(4), 317-336.

Maio, G. R., Bell, D. W., \& Esses, V. M. (1996). Ambivalence and persuasion: The processing of messages about immigrant groups. Journal of Experimental Social Psychology, 32, 513-536.

Maio, G. R., Esses, V. M., \& Bell, D. W. (2000). Examining conflict between components of attitudes: Ambivalence and inconsistency are distinct constructs. Canadian Journal of Behavioral Science, 32, 58-70. Mangleburg, T. F., \& Bristol, T. (1998). Socialization and adolescents' skepticism toward advertising Journal of Advertising, 27(3), 11-21.

Mazaheri, E., Basil, D. Z., Yanamandram, V., \& Daroczi, Z. (2011). The impact of preexisting attitude and conflict management style on customer satisfaction with service recovery. Journal of Retailing and Consumer Services, 18, 235-245.

McGraw, K. M., E. Hasecke, et al. (2003). Ambivalence, uncertainty, and processes of candidate evaluation. Political Psychology, 24, 421-448. 
Messmer, D. J. (1979). Repetition and attitudinal discrepancy effects on the affective response to television advertising. Journal of Business Research, 7: 75-93.

Mitchell, A. A., \& Olsen, J. C. (1981). Are product attribute beliefs the only mediator of advertising effects on brand attitudes? Journal of Marketing Research, 18(August), 318-331.

Mohr, L. A., Eroglu, D., \& Ellen, P. S. (1998). The development and testing of a measure of skepticism toward environmental claims in marketers' communications. Journal of Consumer Affairs 32, 30-55.

Moorman, C. (1990). The effects of stimulus and consumer characteristics on the utilization of nutrition information. Journal of Consumer Research, 17(3), 362-374.

Newby-Clark, I. R., McGregor, I., \& Zanna, M. P. (2002). Thinking and caring about $\mathrm{co}^{-}$ gnitive inconsistency: When and for whom does attitudinal ambivalence feel uncomfortable? Journal of Personality and Social Psychology, 82, 157-166.

Nordgren, L. F., van Harreveld, F., \& van der Pligt, J. (2006). Ambivalence, discomfort, and motivated information processing. Journal of Experimental Social Psychology, 42, 252-258.

Norman, R. (1975). Affective-cognitive consistency: Attitudes, conformity, and behavior. Journal of Personality and Social Psychology, 32, 83-91.
Nowlis, S. M., Kajn, B. E., \& Dhar, R. (2002). Coping with ambivalence: The effect of removing a neutral option on consumer attitude and preference judgments Journal of Consumer Research, 29(3), 319-334.

Oberg, C., Grundstrom, C., \& Josson, P. (2011). Acquisition and network identity change. European Journal of Marketing, 45(9), 1470-1500.

Obermiller, C., Spangenberg, E. R., \& MacLachlan, D. L. (2005). Ad Skepticism: the consequences of disbelief. Journal of Advertising, 34(3), 7-12.

Oreg, S. \& N. Sverdlik (2011). Ambivalence toward imposed change: The conflict between dispositional resistance to change and the orientation toward the change agent. Journal of Applied Psychology, 96(2): 337-349.

Peter, J. P., \& Olson, J. C. (2010). Consumer behaviour \& marketing strategy (9th Ed. ed.) : McGraw-Hill International Ed.

Petty, R. E., Tormala, Z. L., Brinol, P., \& Jarvis, W. B. G. (2006). Implicit ambivalence from attitude change: an exploration of the PAST model. Journal of Personality and Social Psychology, 90(1), 21-41.

Phang, I. G. (2012). Rebranding and its related constructs. International Journal of Commerce, Business and Management, 1(3), 76-85.

Phelps, J. E., \& Hoy, M. G. (1996). The Aad-Ab-PI relationship in children: The 
impact of brand familiarity and measurement timing. Psychology \& Marketing, 13 (1), 77-105.

Phelps, J., \& Thorson, E. (1991). Brand familiarity and product effects on the attitude toward an $\mathrm{Ad}-\mathrm{Brand}$ Attitude relationship. Advances in Consumer Research, 18, 202-208.

Piderit, S. K. (2000). Rethinking resistance and recognizing ambivalence: a multidimensional view of attitudes toward an organizational change. Academy of Management Review, 25(4): 783-794.

Pomerantz, E. M., Chaiken, S., \& Tordesillas, R. S. (1995). Attitude strength and resistance processes. Journal of Personality and Social Psychology \& Mariceting, 69, 408419.

Poon, T. S. C., \& Waring, P. (2010). The lowest of low-cost carriers: the case of AirAsia. The International Journal of Human Resource Management, 21(2), 197213.

Priester, J. R. \& R. E. Petty (1996). The gradual threshold model of ambivalence: Relating the positive and negative bases of attitudes to subjective ambivalence. Journal of Personality and Social Psychology, 71: 431-449.

Priester, J. R. \& R. E. Petty (2001). Extending the bases of subjective ambivalence: Interpersonal and Intrapersonal antecedents of evaluative tension. Journal of Personality and Social Psychology, 80(1): 19-34.

Priester, J. R., Petty, R. E., \& Park, K. (2007). Whence univalence ambivalence? From the anticipation of conflicting reactions. Journal of Consumer Research, 34, 11-21.

Prislin, R., \& Ouellette, J. (1996). When it is embedded, it is potent: effects of general atitude embeddedness on formation of specific attitudes and behavioral intentions. Personality and Social Psychology Bulletin, 22, 845-860.

Randall, J. \& S. Procter (2008). Ambiguity and ambivalence: Senior managers' accounts of organizational change in a restructured government department. Journal of Organizational Change Management, 21(6): 686700.

Roster, C. A. \& M. L. Richins (2009). Ambivalence and attitudes in consumer replacement decisions. Journal of Consumer Psychology, 19: 48-61.

Rudolph, T. J. \& E. Popp (2007). An Information Processing Theory of Ambivalence. Political Psychology, 28(5): 563-585.

Sherif, M., \& Hovland, C. I. (1961). Social judgment New HAven, CT: Yale University Press.

Shimp, T. A., \& Gresham, L. G. (1985). Attitude toward the advertisement and brand attitudes: a classical conditioning perspectiv. Journal of Advertising, 14(1), 10-49.

Shin, Y.S. \& Cha, k.C. (2013). Brand revitalization by strategic repositioning: a case 
study of Korando Sport. Asia Marketing Journal, 14-4(4).

Simonin, B. L., \& Ruth, J. A. (1998). Is a company known by the company it keeps? Assessing the spill over effects of brand alliances on consumer brand attitudes. Journal of Marketing Research, Vol.XXXV, 30-42.

Siomkos, G. J., S. S. Rao, et al. (2001). The influence of positive nad negative affectivity on attitude change toward organizations. Journal of Business and Psychology, 16(1). Stanley, D. J., Meyer, J. P., \& Topolnytsky, L. (2005). Employee cynicism and resistance to organizational change. Journal of Business and Psychology, 19(4), 429-459.

Stuart, H., \& Muzellec, L. (2004). Corporate makeovers: can a hyena be rebranded? Journal of Brand Management, 11(6), 472-482.

Sun, J., \& Wilson, V. L. (2008). Assessing general and specific attitudes in human learning behavior: an activity perspective and a multilevel modeling approach. Educational and Psychological Measurement, 68, 245.

Sverdlik, W. H. J. \& S. Oreg (2009). Personal values and conflicting motivation forces in the context of imposed change. Journal of Personality, 77(5): 1437-1465.

The Star Online (July, 16 ${ }^{\text {th }}$ 2007). Protest held against AirAsia. Retrieved on $9^{\text {th }}$ August 2013 from http://www.thestar.com.my/story. aspx?file $=\% 2 f 2007 \% 2 f 7 \% 2 f 16 \% 2$ fnation $\%$
$2 \mathrm{f1} 18315133 \& \mathrm{sec}=$ nation

Thompson, M. M., Zanna, M. P., \& Griffin, D. W. (1995). Lets not be indifferent about (attitudinal) ambivalence. Attitude strength: Antecedents and consequences. Hillsdale, NJ: Lawrence Erlbaum.

Thorson, E., \& Page, T. J. (1990). On the Ubiquity of Aad $\rightarrow$ Ab Effects. Paper presented at the Annual Meeting of the American Academy of Advertising

van Harreveld, F., Rutjens, B. T., Rotteveel, M., Nordgren, L. F., \& van der Pligt, L. (2009). Ambivalence and decisional conflict as a cause of psychological discomfort: Feeling tense before jumping off the fence Journal of Experimental Social Psychology, 45, 167-117.

Wood, W., Kallgren, C. A., \& Preisler, R. M. (1985). Access to attitude relevant information in memory as a determinant of persuasion: The role of message attributes. Journal of Experimental Social Psychology, 21, 73-85.

World Airline Award (2012). The world best airline list. Retrieved $9^{\text {th }}$ August 2013 from http://www.worldairlineawards.com/awards _2012/Airline2012.htm

World Airline Award (2013). AirAsia enjoys a repeat success after being named the World's Best Low-Cost Airline in the 2013 World Airline Awards. Retrieved $9^{\text {th }}$ August 2013 from http://www.worldairlineawards. com/Awards_2013/lowcost2013.htm 
Yang, D., Davis, D. A., \& Robertson, K. R. (2012). Integrated branding with mergers and acquisitions. Journal of Brand $\mathrm{Ma}^{-}$ nagement, 19(5), 438-456.

Zemborani, M. R. \& G. V. Johar (2007). Attitudinal ambivalence and openness to persuasion: A framework for interpersonal influence. Journal of Consumer Research, 33(March): 506-514.

Zhao, X. Q. and X. M. Cai (2008). The role of ambivalence in college nonsmokers' information seeking and information processing. Communication Research, 35(3), 298-318. 